\title{
Ritual Slaughter, Religious Plurality and the Secularization of Dutch Society (1919-2011)
}

\author{
Bart Wallet
}

\section{Introduction}

In most religious traditions food plays a significant role, both in the sacral and profane spheres of life. On the one hand, culinary traditions are interwoven with the celebration of religious festivals, while on the other hand dietary laws impact daily considerations concerning food. Throughout the centuries, food has functioned as an important identity marker for religious traditions, defining the borders between those who adhere to a certain tradition and those who do not. ${ }^{1}$ What people eat and drink, and how they do so, functions as an expression of their identity. As Feuerbach has pointedly summarized this insight: „Der Mensch ist, was er ißt“. ${ }^{2}$

The practices of ritual slaughter in Judaism and Islam, as part of their respective dietary laws, can likewise be considered expressions of religious identity. ${ }^{3}$ Both textual and oral traditions, or, more specifically, mimetic traditions, have defined how animals should be slaughtered so as to be acceptable for human consumption. The detailed ways in which religious sources have addressed the slaughter of animals is an indication of how these two religious traditions intercede in daily life. One should be wary of reducing religion to a doctrine about the relation between God (or gods) and the world, or to a specific type of spirituality, for such reductions risk overlooking the importance of rituals and practices performed by the faithful. Religious practices, well-defined and precisely fulfilled, are expressions of the system of symbols that a particular religious tradition defines. ${ }^{4}$

1 David M. Freidenreich, Foreigners and Their Food. Constructing Otherness in Jewish, Christian, and Islamic Law (Berkeley: University of California Press, 2011).

2 Ludwig Feuerbach, „Das Geheimnis des Opfers oder Der Mensch ist, was er ißt (1862),“ in Gesammelte Werke 11 (ed. C. H. Beck; Berlin: Akademie-Verlag, 1972), 26-52.

3 Jordan D. Rosenblum, Food and Identity in Early Rabbinic Judaism (Cambridge etc.: Cambridge University Press, 2010), 77-84, 154-157.

4 Michael L. Satlow, “Defining Judaism. Accounting for 'Religions' in the Study of Religion,” Journal of the American Academy of Religion 74 (2006): 837-86o. 
These religious practices are especially challenged by modernity. They were thought to represent the supposed irrational alterity and were thus considered expressions of the anachronistic grounding of certain religious traditions. Many progressive eighteenth- and nineteenth-century intellectuals held Judaism in particular to be an anachronism in the modern era. ${ }^{5}$ Judaism's associated practices, not least ritual slaughter, were consequently considered outdated and overdue for dissolution. Moreover, the social implications of Jewish dietary laws became increasingly debated and contested, especially provisions and restrictions which, in making it all but impossible for practicing Jews to eat with non-Jews, resulted in partial social segregation. ${ }^{6}$

Ritual slaughter thus became both a test case for how modern societies contend with what are often considered socially deviant religious practices, and a challenge for the accepted range of tolerance. As I will demonstrate in this article, the ways in which ritual slaughter was or was not tolerated were an expression of the arrangement of religion in society. Changing ideological and political views of the role of religion, and consequently of attitudes towards religious minorities, immediately influenced the status of ritual slaughter. I will concentrate on one case study: The treatment of ritual slaughter in Dutch society from the start of the twentieth century until the more recent debates in 2011.

From the sixteenth century onward, the Dutch Republic became home to two distinct Jewish communities. Sephardim, known as Portuguese Jews, came and settled primarily in the cities of the province of Holland. They were joined somewhat later by Ashkenazim, from the German countries and from Poland. Both communities displayed a strongly urbanized settlement pattern, but the Ashkenazim were present in more cities and towns than were the Sephardim. For all of them, however, the practice of shechita was of crucial importance, as without kosher food it would have been impossible to settle. The settlement history of Dutch Jewry thus followed a recognizable pattern until well into the nineteenth century: First, a kosher butcher, who functioned also as a shochet

5 Victor Kal, De joodse religie in de modern wijsbegeerte. Van Spinoza tot Derrida (Kampen: Agora, 2000).

6 Michael L. Satlow, Creating Judaism: History, Tradition, Practice (New York etc.: Columbia University Press, 2006), 168-170. 
(ritual slaughterer), would settle in a particular place; other Jewish immigrants would join him there.

There existed no national regulation for ritual slaughter until the first half of the twentieth century. Local authorities, in having to regulate Jewish obligations of shechita, realized that without such permission Jews would be unable to be part of Dutch society. Jewish communities in the larger cities were therefore permitted to have their own 'meat halls', where they could slaughter animals according to halakhic requirements. In Amsterdam, there were two Jewish 'meat halls' - one for the Sephardim, another for the Ashkenazim each performing shehita according to the relevant tradition. ${ }^{7}$ In other cities, Jews were allowed to rent part of the general 'meat hall'; in smaller towns and villages Jewish butchers slaughtered at their own properties.

Two developments in society and national politics caused the subject of ritual slaughter to appear on the agenda of politicians and intellectuals. The first development stemmed from a growing regularization of society during the nineteenth and early twentieth centuries. As an expanding and increasingly effective bureaucracy extended its reach over society, it came to include domains which had previously been unregulated or were dealt with locally. ${ }^{8}$ The meat industry, ranging from butchers to abattoirs, was one of the many domains that became subjected to governmental regulations for the first time.

Second, a growing concern for hygiene stimulated political debate about the status of ritual slaughter. Especially after Pasteur's discoveries relating to bacteria, authorities began to realize the importance of regulations that would prevent the spread of diseases, promote hygiene and educate citizens about healthier lifestyles. Measures ranging from the construction of sanitary sewers and water supply systems to the creation of public parks were undertaken. A number of regulations were issued to guarantee the quality of the citizens' daily food. In Amsterdam, the Portuguese Jew and medical doctor Samuel Sarphati played a major role in the growing attention for hygiene. ${ }^{9}$

Under influence of these two developments, a discussion rose about the practice of shechita and other slaughter methods. Initially, the Jewish method, in which an artery of an unstunned animal is cut in a single continuous

7 Arend H. Huussen, "The Legal Position of the Jews in the Dutch Republic c. 1590-1796," in Dutch Jewry: Its History and Secular Culture (1500-2000) (eds J. Israel and R. Salverda; Leiden: Brill, 2002), 25-42.

8 Hans Knippenberg and Ben de Pater, De eenwording van Nederland. Schaalvergroting en integratie sinds 1800 (Nijmegen: SUN, 1988).

9 Eduard S. Houwaart, De hygiënisten. Artsen, staat \& volksgezondheid in Nederland 1840-189o (Groningen: Historische Uitgeverij, 1991). 
movement with a sharp, unserrated knife, could reckon on a sizable degree of general sympathy, even beyond the Jewish community. It was considered to be more hygienic than other methods, and in 1896 the Minister of War ordered that the Jewish method be used in all military abattoirs. The decision was reconfirmed in $1905 \cdot{ }^{10}$ The decree may have been partially inspired by a desire for convenience, as it would permit all soldiers - Christians and Jews alike - to eat the same kinds of meat, but undoubtedly it expressed also the idea that the shechita was a sound method of slaughter.

However, the generally accepted position of ritual slaughter became complicated by the rise of animal rights movements. Activists argued that shechita was a practice which unnecessarily harmed animals, a complaint that gained power by the introduction of new methods for stunning animals during slaughter. Such opposition was reinforced by the new status of science in society. Scientific discoveries had a huge impact on people's outlook upon the world and were considered a demonstration of the gradual progression of Western civilization. ${ }^{11}$ Hegelian philosophies further strengthened these common ideas. Moreover, scientific research and practices were commonly placed in opposition to traditional practices. Ritual slaughter, for example, was labeled a traditional, pre-scientific practice, which, like other pre-modern slaughtering methods, should be forbidden. The rise of modern anti-Semitism complemented the series of arguments against shechita: Jews were described as alien elements and 'dangerous bacteria' infecting the body of society, and their slaughtering method was held to be clear evidence of this. The language with which ritual slaughter was attacked - it was branded 'medieval', 'barbaric' and 'bloody' - bears witness to anti-Semitic images of Judaism.

Despite criticism from animal rights movements and the new role of science in society, shechita was not forbidden by the first Dutch law to regulate slaughtering practices. In 1919, the parliament voted in favor of a Meat Inspection Act, which was effectuated by Royal Decree in 1920. This law is a clear manifestation of the growing tendencies towards increased regulation and concern for

10 S. L. v. d. Geest, "Ritueele slachtwijze of bij den Christen-slager de halssnede," Nieuw Israëlietisch Weekblad, October 7, 1910.

11 Solange Leibovici, "Zuiverheid als utopie. De foute kinderen van Pasteur," in De hang naar zuiverheid. De cultuur van het moderne Europa (eds R. van der Laarse, A. Labrie, and W. Melching; Amsterdam: Het Spinhuis, 1998), 85-122. 
hygiene. Indeed, the objective of the Meat Inspection Act was not the wellbeing of animals, as the then marginal animal rights movements would have wished, but the health of Dutch consumers. The act contained a number of measures to improve quality standards, and introduced control mechanisms to guarantee Dutch consumers the best meat possible.

Ritual slaughter was permitted under the Meat Inspection Act, but only as an exception. As the prescribed standard method of slaughter included stunning - which, according to the rabbinic experts, was halakhically unacceptable - the Act included three possible exceptions: Home slaughter, emergency slaughter and Jewish ritual slaughter. The shechita nonetheless was still regulated, and only butchers and shokhatim who were accepted by the Dutch rabbinic authorities were allowed to perform ritual slaughters. The Dutch law thus accepted rabbinic authority on this particular subject and integrated it into the system of regulation and control. The Dutch state, inspectors and abattoir directors were given control over the general aspects of competence, hygiene and quality of Jewish butchers, but had to abstain from official opinions on the act of ritual slaughter itself. The liberal principle which states that the government is not knowledgeable in sacra was thus upheld. ${ }^{12}$

The Jewish community was somewhat disappointed by the 1919 act. Spokesmen declared that they would have preferred an equal status of standard and ritual slaughter, as they considered a well-performed shechita at least just as good as stunned slaughter. However, the acceptance of Jewish ritual slaughter in the Netherlands, in a period of history when other countries were putting an end to it, should be interpreted from the broader perspective of how Dutch society dealt with religious diversity. After the introduction of universal suffrage in 1917, a development that had begun in the last half of the nineteenth century now became unmistakably clear: The Netherlands, rather than being an enlightened Protestant nation, as leading intellectuals and politicians in the nineteenth century had preferred to see the Netherlands, was in fact deeply segmented into various minority groups. No group, whether Catholics, Reformed Protestants, liberals or socialists, had a demographic and political majority. The only way in which Dutch politics and society could function was by cooperation between various minority groups.

The specific program for dealing with religious and ideological diversity in Dutch society until the 196os has become known as the 'pillarization model'.13

\footnotetext{
12 Vleeschkeuringswet (1919); "Het ritueele slachten. De praktijk van de Rijkswet," Het Vaderland, December 14, 1922.

13 Arend Lijphart, Verzuiling, pacificatie en kentering in de Nederlandse politiek (Amsterdam: De Bussy, 1968).
} 
Recent debate has rightly questioned various aspects of the standard interpretation of this model, and modified the thesis in such a way that we are able to better distinguish between weak and strong communities. ${ }^{14}$ Yet it is clear that the rationale behind much of Dutch politics during this era was directed by the idea that society consisted of various communities, each of which should be given freedom to express itself publicly. Thus, the Jewish community, although in many aspects a weak community without a large, extended 'pillarized' infrastructure, was permitted to maintain religious practices that were crucial to it. The acceptance of shechita, from the broader perspective of Dutch religion policies, was but one example of the state accommodating religious diversity within society.

However, the Meat Inspection Act did not prevent increasing criticism being directed at shechita in Dutch society from the end of the 1920 and the beginning of the 1930s. Such criticism came from two parties, both of which were small in number and not in a position of notable political and societal influence. The first group of critics were freethinkers who, from an antireligious agenda, objected to religious rites in general, and thus fiercely attacked ritual slaughter. ${ }^{15}$ The second group were animal rights movements, whose criticism of shechita was a continuation in their struggle for better treatment of animals. ${ }^{16}$

The protests were stimulated in part by new methods of stunned slaughtering, such as electric stunning, that had been proposed by scientists. Opponents of ritual slaughter sought to convince rabbinic authorities to accept this new method as halakhically viable. ${ }^{17}$ International politics also empowered Dutch opponents of shechita: As part of dissimilation politics throughout Central and Eastern Europe, ritual slaughter was targeted as being barbaric, bloody and obsolete. With the Nazis' rise to power in Germany, Jewish ritual slaughter was soon forbidden, in a move that garnered political support even from non-Nazi parties, such as the social democrats.

The influence of the German situation was easily discernible in the Dutch debate. For example, Dutch animal rights activists sent a letter of support

\footnotetext{
14 Peter van Dam, Staat van verzuiling. Over een Nederlandse mythe (Amsterdam: Wereldbibliotheek, 2011).

15 "Een geconcentreerde aanval, Nieuw Israëlietisch Weekblad, May 18, 1928.

16 Such as Amor et Justitia, Sofiavereeniging tot bescherming van dieren.

17 W. H. Boomgaard, "Nieuwe bedwelmingswijze voor slachtvee," ("New method of stunning"; article reprinted from Correspondentieblad van de Geldersche vereeniging voor dierenbescherming. Nieuw Israëlietisch Weekblad, July 26, 1929).
} 
to Hitler, congratulating the Nazi Führer on his animal-friendly policies. ${ }^{18}$ In marked contrast, the liberal Jewish politician I. H. J. Vos at one point tried to woe Jewish voters by placing an advertisement in a Jewish weekly that stated that Jewish interests, such as ritual slaughter, were apparently not safe with social democrats. ${ }^{19}$ The main Jewish social democrat, however, Henri Polak, was outraged by Dutch animal rights activists and their attempts to garner domestic political leverage from the German situation. Polak argued that Germany had in fact become one great torture room for Hitler's political opponents and for Jews, and that animal rights activists, rather than protesting against these criminal acts against humans, were lauding Hitler for his love for animals instead. ${ }^{20}$

As long as Dutch politics were organized according to the 'pillarization model', prohibition of shechita stood no chance of being enacted. In this respect, the World War II was in fact an interruption of Dutch policies towards ritual slaughter. After the German occupation of the Netherlands, the second anti-Jewish measure - issued on July 31, 1940 - was a ban on unstunned slaughter practices. ${ }^{21}$ Given the exceptional circumstances, the Dutch chief rabbis opted to make a temporary exception and accept electric stunning as part of the shechita. This lenient decision may have been inspired by concerns for the health of Dutch Jews, the wish to secure jobs in the kosher food industry, the impossibility of importing unstunned kosher meat, and by fear that Dutch Jews might otherwise start using non-kosher meat.

\section{Ritual Slaughter in Post-War Netherlands, $1945^{-1970}$}

Immediately after the war there were discussions among those involved in reconstructing Jewish community life about whether the authorities should be explicitly asked for permission for resuming unstunned shechita. ${ }^{22}$ It was decided not to make such a request, however, as it was feared that the

18 J. van Hessen, "Een telegram aan den Duitschen Rijkskanselier," Het Vaderland, August 23, 1933; "Het telegram aan den Rijkskanselier," August 30, 1933.

19 Advertisement in Nieuw Israëlietisch Weekblad April 21, 1933.

$20 \quad$ Henri Polak, "De groote folterkamer," (article reprinted from Het Volk. Nieuw Israëlietisch Weekblad September 20, 1933).

21 Leeuwarder Courant August 27, 1940; September 4, 1940.

22 The next paragraphs are chiefly based on: Bart Wallet, "In het land van dierenvrienden. Kleine geschiedenis van de rituele slacht," ("In the land of animal friends; a small history of ritual slaughter") Letter \& Geest, Trouw, May 14, 2011. 
authorities would not grant permission. ${ }^{23}$ In line with the general policy of the Dutch government-in-exile, those working to rebuild the Jewish community considered the anti-Jewish measures, like all other German laws imposed during the occupation, to have been revoked. The Netherlands, in general, returned to its juridical status of May 10, 1940. ${ }^{24}$ Ritual slaughter resumed, first in Amsterdam and later elsewhere.

The war years, however, left traces. The animal rights movement soon demanded that the German measure relating to ritual slaughter not be lifted, and some local politicians - like the mayor of Winterswijk - refused to sanction shechita. As research has shown, Nazi propaganda caused a rise in anti-Semitic opinions in Dutch society in the immediate post-war period, and this was apparent when the issue of ritual slaughter was addressed again. In Dutch politics, however, those who wished to return to pre-war 'pillarization' policies prevailed over those who now advocated a new, united and more uniform society. This also meant that the practice of ritual slaughter was permitted again, as it was accepted as a religious act of an acknowledged religious community in Dutch society.

Other things changed, however. Dutch politicians, seemingly indifferent to the exceptional causes underlying the Jewish community's decline, noted that the community had become significantly smaller than it had been before the war. Therefore, they reasoned, the law permitting shechita needed to be adapted to the new situation, and they introduced two new elements into the Meat Inspection Act. First, from January 1, 1949, shechita was no longer permitted everywhere in the Netherlands, but only in official abattoirs in a few selected places: Almelo, Amersfoort, Amsterdam, Arnhem, Deventer, Eindhoven, Enschede, The Hague, 's-Hertogenbosch, Utrecht, Winterswijk and Zwolle. Jewish butchers in smaller places, like Steenwijk, who had only recently resumed business, were hurt by this decision and now had to choose either to quit the business entirely or to become non-kosher. The second new element was the introduction of a criterion of need. Whereas before the war the Jewish butchers had also served a sizable non-Jewish clientele, from now on ritual slaughter would only be permitted per the need of the local Jewish

23 Bart Wallet, "Kosjer Amsterdam. Voedsel, identiteit en samenleving," in Sjehechejanoe. Die ons heeft laten leven. Geschiedenis van de Joodse Gemeente Amsterdam [NIHS] van 1945 tot 2010 (eds B. Wallet, P. van Trigt, and H. Polak; Amsterdam: NIHS, 2011), 142-166.

24 More detailed in Koninklijk Besluit Bezettingsmaatregelen van den 17 Sept. 1944 (Goes: Gebr. Siepman, 1944). 
community. The number of Jews in a given area thus dictated the local quota for kosher meat. ${ }^{25}$

While ritual slaughter was thus again permitted, albeit only for consumption by the Jewish community, a completely new phenomenon now elicited renewed public debate on the issue: Ritual slaughtering for export purposes. From the middle of the twentieth century, the kosher food market had become increasingly international, thanks to new methods for preserving food for longer periods. ${ }^{26}$ Dutch firms, wishing to profit from this development, now sought to export kosher meat to other countries. After the State of Israel was recognized by the Dutch government, in 1949, immediately the question arose whether exports of kosher meat to the new Jewish state were permitted. In Israel there was a tremendous need for kosher meat, which the country's domestic meat production could not meet. The Dutch Ministry of Agriculture initially took a negative position on the issue, and objected to permitting ritual slaughtering for export purposes; the Foreign Ministry, however, was much in favor. After intense debate, economic motives emerged as the decisive factor. Export of kosher meat was permitted to two categories of countries: First, to countries where local production could not answer demand (read: Israel); and second, to countries where ritual slaughter was forbidden (the primary such country being Switzerland).

In post-war Netherlands, most political parties were willing to accept the Jewish minority and its religious practices, albeit within a new, smaller domain. Such willingness was generally based on the view that in the Netherlands Jews, just as Protestants and Catholics, enjoyed freedom of religion and should be permitted to express their faith publicly. Opposition in parliament was voiced only by the small, radical and conservative Reformed Protestant SGP party, which rejected the 'pillarization model' on the grounds that it legitimized religious plurality. The SGP strived for a theocracy, in which the Netherlands would have a Reformed Protestant character. In their opinion, ritual slaughter should therefore no longer be tolerated, and in 1966, sG P Member of Parliament C. N. van Dis demanded that the "horrible suffering of these animals" should end. Moreover, according to Van Dis, ritual slaughter was not prescribed in

25 Kamerstuk Eerste Kamer 1948-1949, nr. 1000 XII, ondernummer 10oo, Rijksbegroting 1949 (Sociale Zaken).

26 Etan Diamond, And I Will Dwell in Their Midst. Orthodox Jews in Suburbia (Chapel Hill: University of North Carolina Press, 2000), 114, 138-139. 
biblical Mosaic law, and thus must have been from later Jewish tradition which he, from his own religious perspective, did not accept as authoritative. ${ }^{27}$

The increasing number of Islamic migrant workers, who later became 'new Dutchmen', altered the debate on ritual slaughter in Dutch society significantly. The Dutch law, thus far, had only permitted ritual slaughter according to the 'Israelite rites' - as defined and controlled by the rabbinate. Ritual slaughter performed according to Islamic rites, so as to obtain halal meat, was still prohibited. In a debate on a measure to advocate the rights of the migrant workers in 1966, Member of Parliament for the social democrats (PvdA), S. van der Ploeg, demanded to know from State Secretary Bartels if there was need to include 'Islamic rites' in the law as well. ${ }^{28}$ After consulting representatives of the Islamic community, Bartels assured Van der Ploeg that it was unnecessary to change the law. What Bartels did not realize, however, was that he had spoken with leaders of the small and relatively progressive Ahmadiyya Muslims, who in no way represented the vast majority of Muslims who had settled in the Netherlands. ${ }^{29}$

Many Muslims, despite the prohibition, chose to slaughter clandestinely, especially on the occasion of Eid al-Adha' (Festival of Sacrifice). This generated problems in society and resulted in police interventions. For instance, in 1969, police had to rescue three Moroccan migrant workers after they were attacked by local residents who were outraged at their wish to ritually slaughter a goat. Politicians and employers realized that they had to take some action ${ }^{30}$ and that, in order to create an attractive employment atmosphere for the much

27 Aanhangsel Tweede Kamer 1965-1966 nummer 512, 973; C. N. van Dis, "Vragen inzake ritueel slachten," De Banier, June 9, 1966; C. N. van Dis, "Beantwoording van de vragen inzake het rituele slachten," De Banier, June 16, 1966.

28 Aanhangsel Tweede Kamer 1965-1966 nr. 419, vragen heer Van der Ploeg (PvdA) in verband met bezwaren Marokkanen tegen nuttigen vlees slachtdieren, January 25, 1965; Antwoord staatssecretaris Bartels, April 26, 1966.

29 W. A. Shadid and Pieter S. van Koningsveld, "Legal Adjustments for Religious Minorities. The Case of the Ritual Slaughtering of Animals," in Islam in Dutch Society: Current Developments and Future Prospects (eds Wasif A. Shadid and P. S. van Koningsveld; Kampen: Kok Pharos, 1992), 2-25.

"Ritueel slachten wekt woede Haagse woonwijk," Leeuwarder Courant, December 8, 1969. 
needed migrant workers, rituals dear to them should be accepted. ${ }^{31}$ In 1975, the Minister of Culture, Recreation and Social Work gave a special dispensation for Islamic ritual slaughter, especially when it was intended for Eid al-Adha. ${ }^{32}$

In order to end continuing clandestine slaughtering, and because of the juridical inequality as compared to the Jewish community, slaughtering according to the "Islamic rites" was finally legally accepted in 1977. Regulations for the Islamic rites were copied from the Jewish example, although comparable organizational structures, skilled professionals and detailed regulations were still lacking. ${ }^{33}$ Since 1977, Jewish and Islamic ritual slaughter in the Netherlands have been closely connected. Despite considerable differences between the practices, together they constitute legal 'ritual slaughter' in Dutch society. The demographic growth of the Islamic minority has resulted in continuing attention to ritual slaughter in the public debate. ${ }^{34}$

The cultural revolution of the 1960 s had meanwhile changed the political climate significantly. The 'pillarized' ideology became discredited, and was replaced by a progressive understanding of the Netherlands as a guiding nation, where discrimination such as had been seen during the war years would never happen again. According to this perspective, ethnic and religious minorities (like the Jewish and Islamic communities) should be accepted and allowed to develop according to their own cultural codes and convictions. Thus the idea of the multicultural society was born. Progressive parties in particular, like the social democratic PvdA, D66, and PPR, used multiculturalism as their main prism in approaching the topic of ritual slaughter. From the beginning of the 1980s until the mid-199os expansion of European institutions and regulations made it necessary to debate the topic in parliament. For the PvdA, ritual slaughter became the test case for the new multicultural society. In 1984, Member of Parliament Flip Buurmeijer advocated the view that integration meant a process of mutual adjustment and therefore Dutch society had to give minorities ample opportunity "to experience their own identity".35

31 Kamerstuk Tweede Kamer 1969-1970, nr. 10504, ondernummer 4, Nota buitenlandse werknemers.

32 "Moslims in ons land mogen ritueel slachten," Nieuwsblad van het Noorden, November 29, 1975 .

Kamerstuk Tweede Kamer 1982-1983, nr. 17011, ondernummer 9, Europees Verdrag inzake slachtdieren; Memorie van Antwoord, July 18, 1983.

34 Iz.M. de Klerk, "Ritueel slachten. Niet alleen gevoelig voor de dieren," typoscript, January 19, 1985 .

35 Handelingen Tweede Kamer 1983-1984, Bijzondere Commissie voor het Minderhedenbeleid, Minderhedennota, February 6, 1984. 
The prevailing political opinion on ritual slaughter was voiced by Prime Minister Wim Kok during a political debate in parliament in 1999: "These are changes that render justice to the developing multicultural society. Rules are adjusted to do justice the normative convictions of newcomers". The Dutch regulated approach to ritual slaughter, in abattoirs and with strict rules, was even regarded as an export product by the "guiding nation". ${ }^{36}$ The Second Chamber demanded, in 1993, that the Minister defend the Dutch approach within the EU. Although the Ministry of Agriculture, while for the moment not addressing ritual slaughter for domestic purposes, sought several times to end the allowance for export, a parliamentary majority did not agree: The liberty of religion should be defended, especially towards countries that defied it, such as Switzerland. ${ }^{37}$

During this period, criticisms of ritual slaughter were voiced especially by those political parties that rejected the idea of multiculturalism. 'Boer' Koekoek, Member of Parliament for the right-wing populist Farmers' Party, in 1976 decried "murdering animals with knifes, axes, hammers and sledges without any stunning". The Secretary of State rejected this description of ritual slaughter and made clear that the Dutch government guaranteed minorities' rights. ${ }^{38}$ The small Protestant parties - SGP, GPV, and RPF - also voiced a critical viewpoint towards ritual slaughter. For them, multiculturalism entailed a further step away from their vision of a Protestant nation, and they therefore tended to be critical of any measure that appeared to further anchor Islam in Dutch society. ${ }^{39}$

36 Cited after: Tetty Havinga, "Ritueel slachten. Spanning tussen religieuze tolerantie en dierenbescherming," in Migratierecht en rechtssociologie, gebundeld in Kees' studies (eds A. Böcker et al.; Nijmegen: Centrum voor Migratierecht en Instituut voor Rechtssociologie Radboud Universiteit, 2008), 211-220.

37 See e.g. Aanhangsel Eerste Kamer 1984-1985 nr. 40, vragen van de heren Van Bemmel (VVD) en Hofman (VVD) inzake ontheffingsbeleid voor export van vlees van ritueel geslachte dieren, April 15, 1985; Antwoord staatssecretaris Van der Ploeg, May 17, 1985.

38 Aanhangsel Tweede Kamer 1976-1977 nr. 714, vragen van de heer Koekoek (BP) inzake ritueel slachten, December 30, 1976; Antwoord staatssecretaris Hendriks (Volksgezondheid en Milieuhygiëne) mede namens de Minister van Landbouw en Visserij, February 25, 1977.

39 Aanhangsel Tweede Kamer 1980-1981 nr. 352, vragen van de heer Van Rossum (SGP) inzake ritueel slachten (October 14, 1980); Antwoord minister Ginjaar (Volksgezondheid en Milieuhygiëne) (December 11, 1980); Handelingen Tweede Kamer 9-10 February 1983; Aanhangsel Tweede Kamer 1982-1983 nr. 1181, vragen van de heren Leerling (RPF) en Wagenaar $(R P F)$ over ritueel slachten, June 17, 1983; Antwoord staatssecretaris Van 
Their critical approach was, however, paled in comparison to the consistent campaign against ritual slaughter waged by the extreme right-wing Centrumpartij. Their representative in parliament, Hans Janmaat, protested often against the "medieval torturing practices". But his struggle was a lonely one, for, according to him, "[t]he politicians lie about so-called xenophobia, anti-Semitism, racism and, for new voters, are willing to cry with the most medieval torturers". ${ }^{0}$ While progressive Dutch people considered ritual slaughter to be a crown jewel of the new multicultural society, Janmaat regarded it as a symbol of the decline of Dutch society. Janmaat argued that a genuinely developed, industrialized country would forbid these primitive religious practices. ${ }^{41}$

\section{$6 \quad$ Ritual Slaughter and the Search for a Secular Dutch Identity}

During the twentieth century criticism against ritual slaughter in the Netherlands had nearly always come from relatively marginal groups in society. This changed rapidly, however, after 2000, when Dutch society was impacted by ' $9 / 11$ ' and the so-called Fortuyn revolt. While 9/11 placed Islam on the international agenda, Dutch politician Pim Fortuyn connected the subject of Islam to social conditions in impoverished city neighborhoods. He demanded uncompromising integration policies and qualified multiculturalism as a total failure. After Fortuyn was murdered, in 2002, major elements of his ideas were integrated into the programs of the main political parties, in an effort to resume control of the debate. Due to this intense debate, support for ritual slaughter quickly waned and the practice became for the first time seriously endangered.

In Dutch society there have been two continuous opponents of the practice of unstunned ritual slaughter. First, the animal rights movement, which has since the end of the nineteenth century consistently opposed ritual slaughter. In 2006, the movement booked a huge success with the entry into parliament of their Party of the Animals. For the first time the animal rights movement had a direct say in parliament and could thus influence political debates.

der Reijden (WVZ) mede namens staatssecretaris Van Zeijl (Landbouw \& Visserij), September 15,1983 .

$40 \quad$ "Medewerker Janmaat zoekt steun bij leden Ekologische Beweging," ("Parliament member Janmaat goes for Ecological Movement members' support") Leeuwarder Courant, February 11, 1983 .

41 Handelingen Tweede Kamer 1983-1984, Bijzondere Commissie voor het Minderhedenbeleid. Minderhedennota (February 27, 1984). 
The Party of the Animals (PvdD) was successful in making animal rights a political issue in The Hague and made ritual slaughter the theme of its first private members' bill. ${ }^{42}$

Second, small parties on the right side of the political spectrum had also been critical since 1945, mainly as an explicit rejection of the ideal of multiculturalism. After 2000, this position was carried on by the Fortuyn party (LPF) and the rightist populist PVV of Geert Wilders. Both parties, however, were significantly larger than the smaller right-wing parties that had preceded them. Moreover, both parties succeeded in entering the center of power, either within government or associated to the government via special construction. The critical stance towards ritual slaughter was no longer voiced only at the margins of Dutch politics, but was for the first time expressed in governmental circles.

The main question, however, concerns the position of the other Dutch political parties. What made these parties, at least in the debates in the Dutch Second Chamber, change their positions? Once again, the broader political stance towards religion in society provides a central clue. The debate on ritual slaughter became redefined, this time along religious versus secular lines. Until the 1990s, ritual slaughter was primarily considered a cultural expression of ethnic minorities. In the twenty-first century, however, ritual slaughter became increasingly regarded as a religious rite, as had been the situation before 1970. This resulted in a regrouping of Dutch politics. The small Christian parties, Christian Union and SGP, together with the larger Christian democrats (CDA) party, now became fierce defendants of ritual slaughter. These parties regarded the public and political debate over ritual slaughter to be a new attack by secular parties on religious practices and they feared that this would develop into subsequent anti-religious policies. Their position was partly instigated by the fact that the Christian parties for the first time in post-war Dutch history held no more than 28 seats in parliament.

Progressive parties regrouped as well. After multiculturalism was abandoned, even by most left and liberal parties, Dutch society began to question itself about what Dutch identity actually meant. If newcomers needed to integrate into Dutch society, what values would they have to accept? Progressive parties answered the question by advocating a new, secular Dutch identity, whose core values were achievements of the 196os, namely, rights for women and homosexuals as well as animal rights. Somewhat surprisingly, perhaps, is that in Dutch politics a broad consensus could be recognized over this

42 "PvdD wil af van onverdoofde slacht," ("PvdD want to get rid of unstunned slaughter") Leeuwarder Courant, March 20, 2008. 
theme - from populist PVV to socialist SP. Ritual slaughter, from this perspective, was a strange and abhorrent religious practice, which did not belong in Dutch society. ${ }^{43}$

The private members' bill presented by the Party of Animals' representative Marianne Thieme passed the Second Chamber of Dutch parliament with an overwhelming secular majority, but failed to convince the Dutch Senate (or First Chamber). However, in this debate it was clear that multiculturalism was no longer the prism through which ritual slaughter was approached; the prism had become the reach of religious freedom in a predominantly secular society. Whereas the Second Chamber deemed ritual slaughter an outdated religious rite that could no longer be tolerated, the Senate decided that such an infringement of religious freedom - and thus citizens' constitutional rights - could not be sanctioned.

\section{7}

\section{Conclusion}

The debate surrounding ritual slaughter in Dutch society is not just about a certain number - some thousands per year - of slaughtered animals, but is in fact tightly intertwined with the political debate about the place of religion in society. The history of this debate over the last hundred years thus offers a prism through which changing convictions can be traced. Three main conclusions can be drawn from this debate.

First, the debate on ritual slaughter emerged in the context of concern about the hygiene of consumers, but gradually shifted to a context of animal rights and of changing moral convictions. Whereas in the first instance the consumers - Jewish and non-Jewish - had been pivotal, animals now became the central point of the debate. The first approach made it possible, for the sake of consumers, to make exceptions to the relevant laws; the second one complicates such exceptions significantly. Indeed, as some politicians argued, there should no longer be discrimination of animals with respect to how they are slaughtered, with some receiving a more 'humane' slaughter than others. Although juridically impossible, in the public debate animals changed from objects into subjects of lawmaking.

Second, the two subsequent arrangements of 'pillarization' and multiculturalism enabled politicians to accommodate religious and cultural diversity

43 A detailed analysis of the argumentation used by proponents and opponents of the practice of ritual slaughter is given in Bart Wallet, "Ritueel slachten en godsdienstvrijheid in een seculiere samenleving," Religie \& Samenleving 7 (2012): 166-183. 
in society. Both models considered Dutch society to be fundamentally diverse and to include various minority groups, which had to cooperate and reciprocate in order to live together. While 'pillarization' had a predominantly religious approach - replaced by a cultural approach in the model of multiculturalism - ritual slaughter was accepted in both models as a crucial rite for Jews and Muslims. This insight raises the question whether multiculturalism in Dutch society was effectively nothing more than a transformation of the 'pillarization' model. The abandonment of multiculturalism in the twenty-first century left Dutch society without a new model for accommodating diversity. The search for a new, secular Dutch majority identity, with the explicit goal of integrating minority groups and assimilating them into the majority Dutch social group, jeopardized the status of ritual slaughter. As a religious rite it was opposed by most of the secular majority, and only a fundamental debate in the Senate on the limits and extents of the constitutional freedom of religion could save ritual slaughter from being banned.

Third, ritual slaughter obtained various shifting symbolic functions in the respective arrangements of politics and religion. During 'pillarization' it was a symbol of acceptance of the Jewish minority, even though a small group rejected it as a supposed threat to the Protestant nature of the Dutch State. During multiculturalism supporters of ritual slaughter considered tolerance for the ritual to be a preeminent example of the acceptance of moral diversity in a multi-ethnic society, whereas opponents considered ritual slaughter to be a telling example of the failures of multiculturalism. In their opinion, multiculturalism was a form of cultural relativism, and they considered "Western civilization" to be more highly evolved than Islamic and Jewish traditions. Ritual slaughter has recently become a symbol in the confrontation between religious and secular articulations of Dutch identity. The first considers ritual slaughter to be a test case for the acceptance of religious rites in a secular society; the latter regards it as a symbol of religious 'medievalism'. In terms of Kathryn McClymond's analysis, one could state that various interpretations of ritual slaughter as sacrificial rite clashed: A reductionist one, in which ritual slaughter is essentially considered to be killing an animal, and a polythetic approach that recognizes the religious meanings attributed to the various stages of the slaughtering ritual. ${ }^{44}$

The Netherlands have not been the only country to debate ritual slaughter. Similar debates have been waged in various European countries, including in countries that have maintained their pre-war bans on ritual slaughter, such 
as Switzerland, Sweden, Norway and Liechtenstein..$^{45}$ Further research should establish in what respects the Dutch debate has been typical of the country and what elements were part of wider European developments. It is nevertheless clear that clashing Enlightenment conceptions - constitutional freedom of religion on the one hand versus qualification of religious rites as anachronistic on the other - have left a legacy with which European politicians and other community leaders are still struggling in their efforts to address the issue of ritual slaughter.

45 Pablo Lerner and Alfredo Mordechai Rabello, "The Prohibition of Ritual Slaughtering (Kosher Shehita and Halal) and Freedom of Religion of Minorities," Journal of Law and Religion 22 (2006-2007): 1-62. 